\title{
If hippopotamuses cannot swim, how did they colonize islands: a reply to Mazza
}

\author{
ALEXANDRA A. E. VAN DER GEER, GEORGE ANASTASAKIS AND GEORGE A. LYRAS
}

How hippopotamuses managed to cross tens or even hundreds of kilometres of open sea to islands and why they did so are, as Mazza (2014) formulates it, challenging problems. The formidable body mass, barrel-shaped build and the relatively stocky, short limbs do not look as those of an apt swimmer. Furthermore, hippopotamuses have been described as bottom-walkers rather than surface swimmers (for details see below). Yet, the fossil record proves their existence on six islands during the Pleistocene. Mazza (2014, p. 2) suggests they were on 'probably most other Mediterranean islands', but there is no evidence to support this claim, despite the abundant fossil record from Sardinia, Corsica, the Balearics, Tilos, Rhodes and Karpathos. Arguing that hippopotamuses cannot swim in open sea, Mazza postulates that in all of these cases the only remaining option for colonization is by land bridge, either fully exposed or only one or two metres deep. If Mazza is right, and hippopotamuses cannot survive overseas dispersal, the available geological evidence should be reconsidered or an alternative explanation has to be looked for. There are some inconsistencies in Mazza's reasoning, which we address below in light of effective collaboration among biologists, palaeontologists, geologist and biogeographers as recommended by Mazza (2014).

There is not one explanation for hippos on islands. A number of insular populations arrived overland or via a very shallow strait that otherwise hampered dispersal of most other faunal elements. This is the case during cold phases of the Pleistocene for Sicily (Hippopotamus pentlandi), Malta (H. melitensis), Java (Hexaprotodon sivajavanicus) and probably during the Holocene for continental shelf islands as Zanzibar and Mafia (Tanzania) (H. amphibius). Mazza cites Bridgland \& Schreve (2004) for the temporary connections that enabled hippopotamuses to spread into these islands, but this is misplaced. Bridgland \& Schreve (2004) describe the quaternary deposits of the Lower Thames and do not mention insular conditions of the British Isles and say nothing about Sicily, Malta, Zanzibar and Mafía. The British Isles were part of the mainland during the entire Pleistocene and the hippos here (H. amphibius) are not considered insular hippopotamuses (in contrast to Mazza). The problem concerns the remaining islands for which there is no geological evidence for a land bridge during the time of colonization. These are Cyprus (H. minor), Madagascar (H. madagascariensis, H. lemerlei, H. laloumena) and Crete (H. creutzburgi).

\section{Geological evidence}

Mazza (2014) lists Cyprus, Madagascar and Crete as cases for which there is, or should be, geological evidence for a Pleistocene land bridge connection. First of all, Mazza exaggerates the various distances to the mainland of these islands. The Mozambique Channel indeed is $430 \mathrm{~km}$ wide, but it is slightly less than $300 \mathrm{~km}$ wide at its narrowest point at the level of Juan de Nova island at low sea level. The relevant distance in these cases is the distance during the time of colonization, which most likely was during a cold phase of the Pleistocene when the sea level was lowest. Even so, these distances, especially for Madagascar, are challenging, even if hippopotamuses were good swimmers. The geological evidence, however, leaves no room for an alternative, despite Mazza's insistence that there must have been land bridges that connected Cyprus, Madagascar and Crete to the mainland during the Pleistocene.

Cyprus has a long history of isolation and segmentation as the Late Miocene, when it developed its present-day configuration and emerged above the water. The paper Mazza cites (Aksu et al. 2005) does not mention the existence of a land bridge between Cyprus and the mainland. The erosional surfaces are attributed to underwater debris-flow deposits (Aksu et al. 2005). The difference in sediment thickness of the Plio-Quaternary succession along the marine continuation of the Kyrenia Ridge (Anastasakis \& Kelling 1991) does not indicate any emergence, but rather reflects shifting sedimentation depocenters of the Cilicia basin during the interval from the Upper Miocene to the Pliocene. Moreover, Pleistocene low sea level coast beaches and river deltas along the south coast in Asia Minor consistently display stratigraphic continuity and submergence, indicating that the edges of the deltas were more inland in the past (Skene et al. 1998). Therefore, the Pleistocene coastline of the mainland to the north of Cyprus is well defined and similar to the present coastline but at some places further inland.

Neither is there geological evidence for a continuous land bridge between Africa and Madagascar during the Pleistocene. McCall (1997) suggested that large areas of the Mozambique Channel along the Davies Ridge were exposed above sea level from the mid-Eocene to the Early Miocene. This suggestion was based on the presence of terrestrial sediments in cores (Leclaire et al. 1989; Malod et al. 1991; Bassias 1992). The Davies Ridge is not the type of structure that could serve as a land bridge. The ridge is a deep ocean-floor structure, which, based on the foraminifera contained within the sedimentary cover, consistently indicates water depths of 1 to $2 \mathrm{~km}$ as the Eocene (Nairn et al. 1991). Rogers et al. (2000) noted that a major part of the ridge remained submerged, and at most a few seamount tops could have been exposed, not connected to each other. Hippopotamus would still have to swim kilometres, not metres, in between, providing that the Pleistocene setting was analogous to that of midEocene - Early Miocene. Actually, McCall (1997) himself excluded hippos from such a colonization scenario, as the temporal window of his palaeogeographical setting well precedes that of the stratigraphical range of Hippopotamus (Upper MioceneHolocene).

Crete has emerged from the sea mostly in the Pliocene (van Hinsbergen \& Meulenkamp 2006). Today, the island is separated from the Peloponnesus (mainland Greece) by an over $100 \mathrm{~km}$ long submerged ridge along which are the present-day islands Kythera and Antikythera and several smaller islets (Lyberis et al. 1982). However, the strait separating Kythera from the Peloponnesus is $280 \mathrm{~m}$ deep and the one separating Antikythera from West Crete over $700 \mathrm{~m}$ deep. Marine seismic stratigraphy of the Kythera-Antikythera strait as well as of the Crete-Karpathos strait indicates Late Miocene submergence and deep marine conditions (Anastasakis \& Dermitzakis 1986). The sedimentary cover suggests that at least since the Early Quaternary similar conditions to those of the present-day prevailed (Anastasakis 1986). This is further verified by cyclic lithostratigraphical development of Upper Pleistocene sedimentation in the straits separating Crete to the west and the east (Anastasakis \& Rohling 1990). Crete was 
thus always separated from the mainland of Greece, even during low sea-level stands of the Pleistocene.

\section{To swim or not to swim}

Hippopotamuses are excellently adapted to a semi-aquatic life. Their skin is smooth, furless and thus hydrodynamically streamlined (Reidenberg 2007). Their feet are partially webbed and their eyes, ears and nostrils are located high on the head on a level with one another and remain above the surface when the animal submerges (Kingdon 1988; Eltringham 1999). When they dive, they close their nostrils tightly and fold their ears against their heads (Eltringham 1999). Furthermore, the limb muscles responsible for propelling the body through water are robust and display extensive fusions (Fisher et al. 2010). What hippos cannot do is float. Adult Hippopotamus have bodies that are slightly denser than water due to their osteosclerotic limb bones. However, hippos do not keep their feet firmly on the bottom, and quadrupedal support is infrequent (Niemitz 2001). Mazza's states that hippos were seldom observed losing contact with the bottom, for which he cites Coughlin \& Fish (2009), who, however, concluded precisely the opposite. Coughlin \& Fish (2009) found that they have only one foot contacting the ground at any time and prolonged unsupported intervals ('flying') during locomotion. Their underwater locomotion was found to be analogous to movement in a micro-gravity environment and similar to a gallop with extended unsupported intervals, which was facilitated by increased buoyancy. That exact behaviour indicates that their specific weight is only slightly higher than that of freshwater, and one might speculate that they are buoyant in salt water. Mazza dismisses the account by Modha (1968) of a hippopotamus that swam in saline water on the ground of the minimal description of the animal in question, whereas other species' interactions with the crocodiles are described in full detail. The likely reason for this is that the interaction with the basking crocodiles, the subject of his report, is minimal as well. The validity of Modha's (1968) statement is important, because Central Island is situated about $9 \mathrm{~km}$ off the nearest coast of Lake Turkana, and the hippopotamus could only have swam there. Lake Turkana has a salinity of 25 per mil (versus 35-39 per mil of sea water). Accounts of saltwater hippopotamuses indicate that they may swim, and the Central Island example may even prove it. Dismissing this example right away hampers the clarification how hippopotamuses reached offshore islands. Adding that Modha's (1968) report is practically ignored by later authors, including ourselves (van der Geer et al. 2010) does not justify continuing doing so.

Mazza correctly dismisses Zanzibar and Mafia (Tanzania) as evidence for the swimming capacities of hippos as these island lie on a continental shelf and are connected to the mainland during low sea-level stands (water depths less than $200 \mathrm{~m}$; for bathymetry, see Masalu 2008). The hippopotamuses reported here as Kersten (1869) may indeed have been confined there after sea level rising instead of having actively swum there. The same may hold for the saltwater-dwelling hippos now living in the Bijagos Archipelago (Guinea-Bissau), some $60 \mathrm{~km}$ off the coast (Lewison \& Oliver 2008)

The feet of adult hippopotamuses are not fully adapted for swimming (e.g. Howell 1930; Coughlin \& Fish 2009), in contrast to those of their young, which are webbed. Juveniles have to dive and swim underwater to suckle (hippo mothers do not leave the water to nurture their young). Young hippos are buoyant and more often move by swimming, propelling themselves with kicks of their back legs. A 1-year-old baby hippopotamus of about $300 \mathrm{~kg}$ survived the tsunami waves of the 2004 Indian Ocean earthquake that swept it into the ocean and was rescued from a sandy coral reef (Hatkoff et al. 2006). A significant part of a hippopotamus herd consists of juveniles, and the chances of survival for this group are much higher than those for adults when swept into the sea and considering their percentage, they could even establish a viable population on the long term.

\section{The definition of success}

Sweepstakes routes, such as tsunami-like transportation, swimming or natural rafting are supposed to result in an insufficient number of founders to establish themselves (Mazza 2014; p. 3). We do not agree with this unsubstantiated statement. For example, early humans reached Flores and evolved into an endemic species (Homo floresiensis). Ruxton \& Wilkinson (2012) argue that even though colonization through the accidental arrival of a group of individuals as a result of highly anomalous natural events (such as tsunamis) is about half as likely to be successful as colonization through a planned voyage, it is still plausible. The probability of successful colonization increases with the size of the initial colonizing group. However, this increase already saturates by around twenty individuals for humans (Ruxton \& Wilkinson 2012), which means that the growth speed of the population remains constant for initial populations of twenty individuals or larger. Perhaps counter-intuitive, the probability of achieving success past this inflection point does not increase with further augmentation of population size (Wolf et al. 1996). A global review suggested a minimum of twelve individuals for ruminants (Komers \& Curman 2000).

The survival for hippopotamuses at sea would decrease dramatically indeed if their skin would dehydrate in sea water as Mazza assumes. A substantial population lives in the Archipelago of Bijagos off Guinea-Bissau and several herds occur along most of the coastline of Gabon (Lewison \& Oliver 2008). Until the early 20th century, hippopotamuses also lived in Zanzibar (Kersten 1869; zur Strassen 1916; Joleaud 1920). Saltwater hippopotamuses have also been reported from Orango Island (Ilha de Orango) and off the island Manada Toto (Lamu Archipelago, Kenya). The hippopotamuses from the coastal Loango National Park (Gabon) gave Loango its nickname 'Land of the surfing hippos' (Fay \& Michols 2004). These hippos seem to love the surf and voluntarily go into the water repeatedly (Quammen 2001). Thus saltwater-dwelling hippos have no skin moisture problems.

Hippopotamuses have low metabolic energy requirements relative to other large herbivores (e.g. Verheyen 1954). On land, hippos can go three weeks without food (San Diego Zoo 2014) and in the wild they may feed every other night (Eltringham 1999). This enhances their potential to survive an overseas dispersal. The absolute amount of food and drinking water required by these large mammals is still large, but if we want to accept that for overseas dispersal merely surviving is good enough, these amounts can be zero, and food deprivation reduces water intake.

Mazza further claims that successful colonizers start as rstrategists to ensure sufficient offspring but eventually adopt a $\mathrm{K}$-strategy to cope with limited resources (based on Lomolino et al. 2010). As appealing as this may sound, this model has never been corroborated despite extensive research. Invasive species today encompass r-strategists (e.g. rats, rabbits) as well as K-strategists (e.g. goats; see Parkes 1993; for feral goats in New Zealand), and one of the most successful colonizers of palaeo-islands are elephants (Lomolino et al. 2013), which are extreme K-strategists. K- and r-strategists can coexist on the same island (e.g. mice and elephants, a usual combination on palaeo-islands), indicating that resource limitation cannot be the sole factor as Mazza seems to imply. In fact, such a dichotomy does not exist - instead, there is a continuous spectrum (Reznick et al. 2002). To conclude that Hippopotamus can be ruled out as successful colonizer based on its reproductive strategy is premature.

\section{Chance dispersal}

We agree with Mazza that hippopotamuses are unlikely rafters. However, to state that there is only one account (Prescott 1959) of a mammal rafting, a jackrabbit (Lepus californicus) is a step too far. Ruxton \& Wilkinson (2012) provided four examples of 
rafting mammals: (1) a dog 'in good health', rescued after three weeks at sea on debris after the 2011 Japanese tsunami; (2) a pregnant woman drifted $100 \mathrm{~km}$ in seven days on floating vegetation after the December 2002 Indonesian tsunami (Morwood \& van Oosterzee 2009); (3) a woman was clinging to a piece of driftwood $80 \mathrm{~km}$ out to sea 6 days after hurricane Mitch struck Honduras in 1998 (Smith 2001); and (4) five men drifted for $2400 \mathrm{~km}$ over 70 days in 1946-47 (Smith 2001). Censky et al. (1998) reported at least twelve iguanas rafted $124 \mathrm{~km}$ on debris after a 1995 hurricane. Finally, Freudenthal et al. (2013) gave some more examples, which we will not repeat here, Rafting may be a multiple event, as oceanic current patterns commonly lead not only to the aggregation of floating objects but also to their deposition on the shore concentrated in both space and time (Hinojosa et al. 2011). This increases the success of colonization because individual 'rafts' might arrive at the same location, thus increasing the amount of founders.

There is also indirect evidence of successful rafting. The Pleistocene giant rice rat (Megaoryzomys curioi) of Santa Cruz of the Galapagos arrived long before humans came with their boats (Steadman \& Ray 1982) (the other endemic rice rat, Nesoryzomys swarthi, of Isla Santiago probably represents a later colonization). The Galápagos Islands are $972 \mathrm{~km}$ offshore, so the ancestors of this rat probably arrived by rafting (see van den Hoek Ostende et al. (2009) for more examples).

Another type of sweepstakes dispersal is being swept into the sea. Rip currents may do so, but, as Mazza correctly points out, this is an unlikely initiator of a sweepstakes dispersal as typically, rip currents stretch at most $1.4 \mathrm{~km}$ out to sea (Dalrymple et al. 2011). This could explain the dispersal of a herd of saltwater hippopotamuses to continental shelf islands such as Sicily and Malta, but certainly not to Crete, Cyprus and Madagascar. A more likely cause is cataclysmic flooding of main river and lake systems.

Mazza overlooks geological time. However, unlikely a dispersal might be, its likelihood increases with increasing time. The fact that the jackrabbit (the example of the naturally rafting mammal) was not able to successfully colonize one of the three Channel Islands in the over 1.5 million years of its existence as a species is beside the point. The chances are low, so for the vast majority of species and islands, the outcome of this lottery is zero. The changes are, however, not exactly zero, and in the 2 million years Hippopotamus was around, it managed to establish itself after overseas dispersal on three islands as shown by the fossil record. As Ruxton \& Wilkinson (2012) conclude elegantly, it is important to distinguish between highly improbable and impossible events. Accidental arrival of hippopotamuses on an island is merely improbable for any particular island in any particular year, but given the large number of islands, tsunamis and river flood events, such colonization might be quite likely to happen to at least some islands over a time period of two million years.

Acknowledgements. - We thank L van den Hoek Ostende and I de Vos for fruitful discussion on dispersal of mammals to islands. We also thank the reviewers and the editor for their valuable comments. This research has been cofinanced by the European Union (European Social Fund - ESF) and Greek national funds through the Operational Program 'Education and Lifelong Learning' of the National Strategic Reference Framework (NSRF) - Research Funding Program: THALIS UOA- Island biodiversity and cultural evolution: Examples from the Eastern Mediterranean, Madagascar, Mauritius and Philippines during the past 800,000 years (MIS375910, KA:70/ 3/11669).

Alexandra A. E. van der Geer [alexandra.vandergeer@naturalis.nl], Department of Geology, Naturalis Biodiversity Center, P.O. Box 9517, 2300 RA Leiden, the Netherlands; George Anastasakis [anastasakis@geol.uoa.gr], George A. Lyras_[glyras@geol.uoa.gr], Department of Historical Geology and Palaeontology, Faculty of Geology and Geoenvironment, National and Kapodistrian University of Athens, 15784 Athens, Greece

\section{References}

Aksu, A.E., Calon, T.J. \& Hall, J. 2005: The Cilicia-Adana Basin complex, Eastern Mediterranean: neogene evolution of an active fore-arc basin in an obliquely convergent margin. Marine Geology 221, 101-133.

Anastasakis, G. 1986: The continental margin of the Kithira-Antikithira-NW Cretan straits: shallow structure and evolution during the Upper Cenozoic. Bulletin of the Geological Society of Greece 20, 369-381.

Anastasakis, G. \& Dermitzakis, M.D. 1986: Upper Cenozoic connections of the Aegean: marine geological evidence as compared to the fossil mammals of the region. Rapport Commission International Mer Méditerranee 30, 70.

Anastasakis, G. \& Kelling, G. 1991: Tectonic connection of the Hellenic and Cyprus arcs and related geotectonic elements. Marine Geology 97, 261-277.

Anastasakis, G. \& Rohling, E.S. 1990: Upper Quaternary climatic cycles as evidenced by lithofacies associations and planctonic foraminifera of sapropel sequences in the outer periphery of the Hellenic Arc. Thalassographica 13, 7-16.

Bassias, Y. 1992: Petrological and geochemical investigations of rocks form the Davie Fracture Zone (Mozambique Channel) and some tectonic implications. Journal of African Earth Sciences 15, 321-339.

Bridgland, D.R. \& Schreve, D.C. 2004: Quaternary lithostratigraphy and mammalian biostratigraphy of the Lower Thames terrace system, south-east England. Quaternaire 15, 29-40.

Censky, E.J., Hodge, K. \& Dudley, J. 1998: Over-water dispersal of lizards due to hurricanes. Nature 395, 556.

Coughlin, B.L. \& Fish, F.E. 2009: Hippopotamus underwater locomotion: reduced gravity movements for a massive mammal. Journal of Mammalogy 90, 675-679.

Dalrymple, R.A., MacMahan, J.H., Reniers, A.J.H.M. \& Nelko, V. 2011: Rip currents. Annual Review of Fluid Mechanics 43, 551581.

Eltringham, S.K. 1999: The Hippos: Natural History and Conservation, 256 pp. T. \& A.D. Poyer, London.

Fay, J.M. \& Michols, M. 2004: In the land of the surfing hippos. Gabon's Loango National Park. National Geographic Magazine August 1, (2004), 101-127.

Fisher, R.E., Scott, K.M. \& Adrian, B. 2010: Hind limb myology of the common hippopotamus, Hippopotamus amphibius (Artiodactyla: Hippopotamidae). Zoological Journal of the Linnean Society 158, 661-682.

Freudenthal, M., van den Hoek Ostende, L.W. \& Martín-Suárez, E. 2013: When and how did the Mikrotia fauna reach Gargano (Apulia, Italy)? Geobios 46, 105-109.

van der Geer, A.A.E., Lyras, G.A., de Vos, J. \& Dermitzakis, M. 2010: Evolution of Island Mammals: Adaptation and Extinction of Placental Mammals on Islands, 479 pp. Wiley-Blackwell, Chichester.

Hatkoff, I., Hatkoff, C., Kahumbu, P. \& Greste, P. 2006: Owen \& Mzee: The True Story of a Remarkable Friendship, $40 \mathrm{pp}$. Scholastic Press, New York.

Hinojosa, I.V., Rivadeneira, M.M. \& Thiel, M. 2011: Temporal and spatial distribution of floating objects in coastal waters of central-southern Chile and Pategonian fjords. Continental Shelf Research 31, 172-186.

van Hinsbergen, D.J.J. \& Meulenkamp, J.E. 2006: Neogene supradetachment basin development on Crete (Greece) during exhumation of the South Aegean core complex. Basin Research $18,103-124$.

van den Hoek Ostende, L.W., Meijer, H.J.M. \& van der Geer, A.A.E. 2009: A bridge too far. Comment on 'Processes of island colonization by Oligo-Miocene land mammals in the central Mediterranean: new data from Scontrone (Abruzzo, Central Italy) and Gargano (Apulia, Southern Italy)' by P.P.A. Mazza and M. Rustioni. Palaeogeography, Palaeoclimatology, Palaeoecology 279, 128-130.

Howell, A.B. 1930: Aquatic Mammals, 338 pp. Charles C. Thomas, Springfield. 
Joleaud, L. 1920: Contribution à l'étude des Hippopotames fossiles. Bulletin de Société Géologique de France (série 4), 20, $13-$ 26.

Kersten, O. 1869: Baron Carls von der Decken's Reisen in OstAfrika in den Jahren 1859 bis 1861, Vol. 1, 335 pp. C.F. Winter, Leipzig.

Kingdon, J. 1988: East African Mammals: An Atlas Of Evolution in Africa, Vol. 3, Part B, Large Mammals, 450 pp. The University of Chicago Press, Chicago.

Komers, P.E. \& Curman, G.P. 2000: The effect of demographic characteristics on the success of ungulate re-introductions. Biological Conservation 93, 187-193.

Leclaire, L., Bassias, Y., Clocchiatti, M. \& Segoufin, J. 1989: Le Ride de Davie dans le Canal de Mozambique: approche stratigraphique et géodynamique. Comptes Rendus de l'Académie des Sciences de Paris II 308, 1077-1082.

Lewison, R. \& Oliver, W. (IUCN SSC Hippo Specialist Subgroup) 2008: Hippopotamus amphibius. In IUCN 2014 IUCN Red List of Threatened Species. Version 2014.1. www. iucnredlist.org. Downloaded on 24 June 2014.

Lomolino, M.V., Riddle, B.R., Whittaker, R.J. \& Brown, J.H. 2010: Biogeography, 4th edn, 764 pp. Sinauer Associates, Sunderland.

Lomolino, M.V., van der Geer, A.A., Lyras, G.A., Palombo, M.R., Sax, D.F. \& Rozzi, R. 2013: Of mice and mammoth: generality and antiquity of the island rule. Journal of Biogeography 40, 1427-1439.

Lyberis, N., Angelier, J., Barrier, E. \& Lallemant, S. 1982: Active deformation of a segment of arc: the strait of Kythira, Hellenic arc, Greece. Journal of Structural Geology 4, 299-311.

Malod, J.A., Mougenot, D., Raillard, S. \& Maillard, A. 1991: Nouvelles contraintes sur la cinématique de Madagascar: les structures de la chaîne de Davies. Comptes Rendus de l'Académie des Sciences de Paris II 312, 1639-1646.

Masalu, D.C.P. 2008: An overview of the bathymetry and geomorphology of the Tanzania EEZ. The Open Oceanography Journal 2, 28-33.

Mazza, P.P.A. 2014: If hippopotamuses cannot swim, how did they colonize islands? Lethaia. Epub ahead of print: DOI 10. 1111/let.12074.

McCall, R.A. 1997: Implications of recent geological investigations of the Mozambique Channel for the mammalian colonization of Madagascar. Proceedings of the Royal Society of London, B, Biological Sciences 264, 663-665.

Modha, M.L. 1968: Basking behaviour of the Nile crocodile on Central Island, Lake Rudolf. East African Wildlife Journal 6, $81-88$.

Morwood, M. \& van Oosterzee, P. 2009: A New Human. The Startling Discovery and Strange Story of the 'Hobbits' of Flores, Indonesia, 287 pp. Left Coast Press, Walnut Creek.
Nairn, A.E.M., Lerche, I. \& Iliffe, J.E. 1991: Geology, basin analysis, and hydrocarbon potential of Mozambique and the Mozambique Channel. Earth-Science Reviews 30, 81-124.

Niemitz, C. 2001: Astronautentraining im Flusspferdhaus?: Kinematische Studien über die Auswirkungen der Schwerkraft auf die Fortbewegung. Bongo Berlin 31, 63-68.

Parkes, J.P. 1993: Feral goats - designing solutions for a designer pest. New Zealand Journal of Ecology 17, 71-83.

Prescott, J.H. 1959: Rafting of a jack rabbit on kelp. Journal of Mammalogy 40, 443-444.

Quammen, D. 2001: End of the line: megatransect, part three. National Geographic Magazine, August 2001, 74-103.

Reidenberg, J.S. 2007: Anatomical adaptations of aquatic mammals. The Anatomical Record 290, 507-513.

Reznick, D., Bryant, M.J. \& Bashey, F. 2002: R-and K-selection revisited: the role of population regulation in life-history evolution. Ecology 83, 1509-1520.

Rogers, R.R., Hartman, J.H. \& Krause, D.W. 2000: Stratigraphic analysis of Upper Cretaceous rocks in the Mahajanga Basin, northwestern Madagascar: implications for ancient and modern faunas. Journal of Geology 108, 275-301.

Ruxton, G.D. \& Wilkinson, D.M. 2012: Population trajectories for accidental versus planned colonisation of islands. Journal of Human Evolution 63, 507-511.

San Diego Zoo, 2014: Hippopotamus. http://animals.sandiegozoo.org/animals/hippo.

Skene, K.I., Piper, D.S.W., Aksu, A.E. \& Syvitski, J.P.M. 1998: Evaluation of the global oxygen isotope curve as a proxy for Quaternary sea level by modeling of delta progression. Journal of Sedimentary Research 68, 1077-1092.

Smith, J.M.B. 2001: Did early hominids cross sea gaps on natural rafts? In Metcalfe, I., Smith, J.M.B., Morwood, M. \& Davidson, I. (eds): Faunal and Floral Migration and Evolution in SE AsiaAustralasia, 409-416. Swets \& Zeitlinger, Lisse.

Steadman, D.W. \& Ray, C.E. 1982: The relationships of Megaoryzomys curioi, an extinct Cricetine rodent (Muroidea: $\mathrm{Mu}-$ ridae) from the Galápagos Islands, Ecuador. Smithsonian Contribution to Paleobiology 51, 1-23.

zur Strassen, O. 1916. Brehms Tierleben. Allgemeine Kunde des Tierreichs, 4th edn, Vol. 4, Säugetiere, 714 pp. Bibliographisches Institut, Leipzig.

Verheyen, R. 1954: Monographie éthologique de l'hippopotame, 91 pp. Institut des Parcs Nationaux du Congo Belge, Brussels.

Wolf, C.M., Griffith, B., Reed, C. \& Temple, S.A. 1996: Avian and mammalian translocations: update and reanalysis of 1987 survey data. Conservation Biology 10, 1142-1154. 